\title{
Towards a Lutheran Theology of Bodily Healing
}

\section{Introduction}

The relationship between religion and health is presently widely recognized and discussed in several contexts, both religious and secular. ${ }^{1}$ However, in Lutheran theology, the topic of bodily healing has received limited attention. Given that Lutheran theology has had a strong emphasis on Scripture, and the dominant position Jesus has as a healer in the gospels, the lack of emphasis on this part of his ministry in Lutheran theology is striking. Can it be that the Lutheran understanding of the gospel is an obstacle to developing this topic further? ${ }^{2}$ As we shall see below, some scholars suggest this is the case. ${ }^{3}$

Contemporary theological concerns shape the interest behind the following elaborations. In the present situation, health and healing are high on the list of what people care about and in which they are interested. Although religious healing related to "healing rallies" often has given spiritual healing a bad reputation, many people seem to seek for healing within different contexts related to religion and spirituality that does not get the same amount of negative public attention. Moreover, they often have positive experiences with it. However, if you ask for a Lutheran theology that can interpret or offer some framework for understanding what takes place in religious contexts that provide possibilities for bodily healing, there is not much to be found. Thus, we need an explicit Lutheran theological interpretation of experiences of bodily healing.

Healing may have to do with recovery, restoration, or improvement of healthrelated conditions, but not necessarily of the kind that we can attribute to factors that the established contemporary paradigm of medical knowledge acknowledges. There is presently sufficient evidence to suggest that healing defined thus also takes place outside the established knowledge of modern medicine, and in religiously shaped contexts as well. ${ }^{4}$ Accordingly, healing should be seen as a comprehensive

1 Cf. Fraser N. Watts, ed., Spiritual Healing: Scientific and Religious Perspectives, Cambridge: Cambridge University Press, 2011. For a sociological account of this claim, see Meredith McGuire, Lived Religion: Faith and Practice in Everyday Life, Oxford, 2008, and from a more theological point of view, Stephen Pattison, Alive and Kicking: Towards a Practical Theology of Illness and Healing, London: SCM Press, 1989.

2 One distinctively Lutheran contribution can be found in Ted Peters, "Wholeness in Salvation and Healing", in Lutheran Quarterly 5 (1991): 297-314.

3 The following considerations have been developed within a more comprehensive context in Jan-Olav Henriksen, and Karl Olav Sandnes, Jesus as Healer: A Gospel for the Body, Grand Rapids: Eerdmans, 2016.

${ }^{4}$ In the Nordic countries, see works on contemporary dimensions of healing by Lars Ahlin, Krop, sind — eller nåd?: Alternative hehandlere og Spiritualitet i Danmark, Höjberg: Univers, 2007; Anne Kalvig, Andeleg belse: Ein kulturanalytisk studie av menneske- og livssyn hos alternative terapeuter, doktorsritgerð, Háskólinn í Bergen, 2011. For a more comprehensive overview globally, see Craig S. Keener, Miracles: The Credibility of the New Testament Accounts, Grand Rapids: Baker Academic, 2011, and for anthropological studies, cf. Thomas J. Csordas, The Sacred Self: A Cultural Phenomenology of Charismatic Healing, Berkeley: University of California Press, 1994, and his Body/Meaning/Healing, New York: Palgrave Macmillan, 2002. 
and inclusive notion. Moreover, I want to emphasize that healing as here understood has an embodied dimension, i.e., it is not only a question of coming to terms with "the meaning of" illness or disease, or of improving "spiritually." The embodied dimension is not arbitrarily chosen: it points to an element in Lutheran theology that is not the main focus of this tradition-which is on faith without works. Hence, one could say that the basic orientation of Lutheran theology points toward an emphasis on the justification of the "inner person" that makes it harder to develop a notion of how God works for salvation in acting with the body for the benefit of it-and not only for the benefit of the soul or "inner human" through the forgiveness of sins.

\section{Is there a distinctively Lutheran approach to bodily healing? Challenges from Porterfield and Wingren}

Two important studies may point in the direction of finding an answer to why there is the claimed lacuna in Lutheran theology. These are studies by Amanda Porterfield and Gustaf Wingren, both of which point clearly to the challenges of Lutheran theology when it comes to an interpretation of bodily healing. I will present them briefly here, to provide a backdrop for the interpretation of some texts by Luther in the next section.

Porterfield, in her excellent study of Healing in the History of Christianity, ${ }^{5}$ makes some significant observations that may serve to frame the following interpretation of Luther and the Lutheran tradition's approach to texts about healing (and accordingly: also to events claimed to result in healing). I use her work here not only for establishing this framework but also to try to identify more clearly the distinctive character that Luther's interpretation of texts about healing displays.

Porterfield points to how there is a significant difference between theologians in the West compared to the East when it comes to the theological interpretation of healing. In the West, those who "followed in the path of Augustine did not embrace miraculous healing as a manifestation of mystical experience as straightforwardly as Eastern theologians did." 6 There are a few elements worth commenting on with regards to her observations here: First of all, she seems to be right in identifying one of the main influences in the West as Augustine. In the two sermons analyzed from Luther's hand below, the references to Augustine's interpretation are abundant. Moreover, whereas one in the East could see events of healing as instances of mystical experience, and thereby also interpret them as something happening to the body that had spiritual significance but included and affected the body, this was not the case in the West in the same manner. Here, "healing was more often associated with manipulation of spiritual forces, and thus more vulnerable to condemnation as magic."' She continues:

\footnotetext{
5 Amanda Porterfield, Healing in the History of Christianity, Oxford: Oxford University Press, 2005. I emphasize that I do not analyze Porterfeild's work in detail here, as my interest is simply to present her main claims and conclusions. 
Along with many Catholic reformers who criticized the Roman Church for exploiting people's belief in miracles, Luther and Calvin downplayed the significance of external signs of the spirit and argued that miracles had largely ceased at the dose of the apostolic era. Critical of what they perceived to be the magical elements of Roman ritual and their venal exploitation, Luther and Calvin acknowledged the healings performed by Jesus and his apostles as miraculous signs of divine authority but wrote little about them. ${ }^{8}$

Porterfield does not distinguish much between different strands of Reformation theology when it comes to healing. In her view, all of the reformers, including Luther, interpreted healings along lines that significantly influenced the possibility of allowing them to be interpreted as a part of everyday experience. By pointing to how they were seen as signs of divine authority, as well as determining them to have a miraculous character, instances of healing were placed more in the sphere of the supernatural and the past than in a sphere of the everyday and the present. Not only do the reformers thereby place the experiences of healing in a specific religious sphere, but they also restrict the possibility for connecting what people may have of such experiences to positive religious significance, as long as these experiences are not possible to interpret as manifestations of divine authority or related to salvation. These decisions for interpretation, in turn, may have much to say for the lack of an extensive positive interpretation of healing practices within a Lutheran context, and should not remain unquestioned.

Porterfield says that even though practices that could be interpreted as magic when it comes to seeking healing persisted, "the reformers nevertheless succeeded in furthering a theological distinction between religion and magic that Christian apologists since the first century insisted on." "Furthermore, their insistence on the necessity of faith leads to a focus on the "interior human being," a point that has already been taken up by Gustaf Wingren before Porterfield's work.

Wingren is a relevant interlocutor in this context because much of his theological work was aimed at relating creation and redemption to each other. He wanted to overcome the sharp distinction or separation between them and to show that the Gospel cannot be understood unless one also has a robust understanding of what God does in creation. Wingren also seems to be one of the few scholars who has identified the problem here discussed from the point of view of Lutheran theology.

In his study Gospel and Church, ${ }^{10}$ Wingren points to how Luther builds up a sharp distinction between the human conscience and the human body, which correlated with his distinction between gospel and law. Pointedly, he speaks about how the Gospel, according to Luther, may do away with the guilt experienced in human conscience, but it does not lead to any healing of the body. Wingren furthermore points to how the early church and its doctrine about recapitulatio, especially in Irenaeus, identified the fundamental contradiction in human life as the struggle between life and death. Thereby one was able to employ stories about Jesus as a healer in the synoptic Gospels in a fruitful manner. They are not only stories about divine authority and the human call to faith and obedience but are about God's care for and recapitulation of the body as part of God's creation. Hence, Ireneus

\footnotetext{
8 Ibid.

9 Ibid., 25.

${ }^{10}$ See Gustaf Wingren, Gospel and Church, St. Paul: Augsburg Fortress, 1991, 154ff. I owe the reference to Wingren here to my doctoral student Tron Fagermoen.
} 
can connect the stories about Jesus as a healer to an interpretative framework that allows for recognizing the continuation in God's work for creation and redemption in a more profound manner than does Luther.

Wingren's challenge to a contemporary Lutheran theology of bodily healing could accordingly be stated thus: Is there a Gospel for the body? Alternatively, is the gospel only for the consolation of the troubled conscience? If there is such a gospel for the body-what would be its main features? Before answering that question, we need to substantiate the claim that there is a lacuna in Lutheran theology about bodily healing somewhat more.

\section{Luther's approach to texts about healing}

Porterfield claims that "Luther's voluminous commentaries on the Bible simply ignore the gospel passages that describe Jesus' activity as a healer."11 An examination of Luther's works offers considerable warrants for this claim. Luther's theological rejection of entering into a more comprehensive development of a theology of healing is dictated by his theological concerns and his front against his present-day Roman Catholicism. There he found the idea that healing and other things that could be interpreted as expressions of God's favor "might be obtained by means of penance, prayers, saints, or any power inherent in the elements of the Eucharist." 12 Such a view would fly in the face of his conviction of the justifying grace of God as accessible by grace alone.

Luther's theological focus is on faith and obedience to God. This focus implies a rejection of any manipulative efforts to change his will. Nevertheless, Porterfield also recognizes that Luther saw "humanity's need for healing and Christ's role in attending to that need." However, no rituals or practices can provide the necessary cure, and accordingly, the body which provides opportunities for healing, as well as the body which may be subject to practices of healing, are not taken into consideration as theologically relevant. What can make human beings well is the love and forgiveness of Christ. This strict perspective is a consequence of how Luther sees the sole and only problem of human existence as related to sin towards God.

If we examine Luther's work, e.g., his sermons on the Gospel of John, ${ }^{13}$ the findings are predominantly on the negative side in a way that substantiates these observations. He did not preach on the royal nobleman in chapter 4, or the crippled man at the well of Bethesda in chapter 5, or about the man born blind in chapter 9 (He does preach on this text in another context, though: see below). Also, when we look at other texts of his that address healing events, the result is fairly meager. Mostly, Luther focuses on faith and the promises of God rather than on what God does here and now.

Let me demonstrate this point by analyzing in some detail two early texts of his that may well illustrate the predominant trend in Luther's approach to stories about

\footnotetext{
11 Porterfield, 24.

12 Ibid.

${ }_{13}$ Martin Luther, Luther's Works, American ed., Vol. 22-24. (Hereafter abridged LW with references in brackets in the text.)
} 
healing, namely Two Lenten Sermons from 1518. The first is on the man born blind in John 9, the second on the Raising of Lazarus in John 11.

At the outset of the first of these sermons, Luther refers to Augustine, who emphasized how all that Christ did is both works and words (LW 51: 36). For Augustine, works were facts, whereas words were signs. The words are accordingly important because they teach and signify something, whereas the works are what they are because something happened due to his acting. Luther emphasizes, however, that the event where the blind man received his sight is also a word: the message is not about what happened to the blind man and his body (eyes), but about every human being: "For we are all blind and our light and our illumination come solely from Christ, our good and faithful God" (ibid).

It is worth commenting on the move Luther makes here: in order to actualize the text for his listeners, he must identify and emphasize the content of the story as a sign: The meaning and lasting significance of it is not related to the changing embodied conditions of the man in question, but primarily to what this story tells the listeners about their own "spiritual" blindness. The move from the bodily to the spiritual allows Luther accordingly to move away quickly from the actual event as something in need of being interpreted as theologically significant in itself. Instead, "The blind man was a sign of the blindness that lay hidden in our hearts" (LW 51, 37).

From a hermeneutical point of view, this move is not surprising. All that happens to the body (as the rest of nature) needs interpretation if it is to have some significance or meaning for humans. We interpret what happens to the body all the time. However, as opposed to Luther's interpretation, when we do so, we do it in order to understand the body and what happens to it, not in order to understand ourselves independent of our embodied condition. It is the move away from the body, and the emphasis on a meaning in the event itself that does not include the body in the message of the Gospel, that is the most problematic element in Luther's interpretative strategy here.

By his choice of interpretative move about the actual text in John 9, Luther focuses on human ignorance and weakness when knowing about and facing God. The allegorical interpretation of the text discloses that it is primarily not about God caring about human embodiment and its wellbeing. Instead, "The man in the Gospel is only a figure of that other blindness which is in our soul." (LW 51: 38, emphasized by me).

In this sermon, there are two other features that suggest why Luther has trouble interpreting bodily healing in a manner that expresses God's concrete care, compassion, and mercy concerning the body. The lack of these features thereby also suggests the absence of features that could motivate a more positive interpretation of the actual event of healing: First, he describes the incarnation as one in which Christ "put off the form of God and was found in the form of man, in sinful flesh, though he never sinned; nor could he ever sin" (LW 51: 38). It is hard not to see this description of human flesh as something related to and interpreting the human body. Even Christ is born "in sinful flesh," i.e., in a body. These interpretative decisions suggest a negative approach to the body as such, and this negative attitude may then, in turn, be seen as mirrored in Luther's lack of emphasis on what happens 
to the actual body. Second, Luther here also describes sickness and death as sent by God $^{14}$, thereby establishing a context for these phenomena which is not seen in opposition to what God does when God instigates events of bodily healing (cf. LW 51: 41). Instead, these are interpreted as features that should help the believers to fix their eyes on the mercy of God amid all despair-God does it to help them see what matters and not! Moreover, what matters is not the body, but the faith of the soul.

The allegorical interpretation of events related to bodily illness and health is continued in the other of the 1518 Lenten Sermons, i.e., on the raising of Lazarus. Here, Luther starts by referencing the scarce reports on raisings of the dead in the Gospels - three altogether, and he does not discuss the historical problems related to these, but moves again quickly and by means of a reference to Augustine to an allegorical interpretation where these three dead represent three kinds of sinners (LW 51: 44f.). All three stories then signify how Christ loves the sinner. Even when the narrative describes how the sisters of Lazarus were struck with bereavement and wept for the death of their brother, Luther interprets this text as not primarily showing what happens in the severing of the bonds between human, embodied persons, but rather as how "we learn that they were all in unbelief and sin" (LW 51: 48).

Now, one possible explanation for this dis-embodied interpretation displayed in these two sermons may be that Luther doubts the historical accuracy of the events reported. That is, however, not a very likely explanation. It is more likely to see his choice of interpretation as resulting out of a rather one-sided theological focus on faith and obedience, which does not leave much room for a positive theological interpretation of events that relate to or specifically include the human body and its condition. However, unlike Calvin, who is somehow precluded from seeing any theological significance in what happens to the body according to the non capax, Luther has in principle other means for recognizing that God can be at work in, with and under the conditions of the created world in its embodied character. Therefore, one should see this lack or lacuna in Luther's thinking more as a result of his deliberate one-sidedness than as a result of the same features that led Calvin to his critical assessment of contemporary claims about the significance of healing. In effect, though, they seem to end up with the same meager result.

\section{Filling the lacuna: Strands in a Lutheran theology of bodily healing}

Can there be a Gospel for the body? How is healing a part of this gospel? There are several ways to go about to answer this question in the affirmative. The following sketch is meant as a proposal for a Lutheran theology of healing that takes both creation and redemption into consideration. As such, it aims at opening up a discussion of what could also be a specific Christian approach to healing that displays its distinctiveness in dialogue with other religious traditions' interpretation of healing.

\footnotetext{
${ }^{14}$ Admittedly, Luther does not always see death as a result of the will of God. Cf. his late "Comfort for Women Who Have Had a Miscarriage", LW 43: 247ff. (1542).
} 
If the gospel is mainly about redemption from sin, one has to ask if this redemption should not also be considered related to the body. Indeed, such an approach may be possible if we take our point of departure in the healing ministry of Jesus, which addresses all aspects of human life, including bodily welfare. Sin may mean an impeded or corrupted relation to the God who offers life to creation. We may thus define sin as that which destroys life and life-relations and distorts the free flow of life articulating itself in the different realms of human experience. Sin is thus also a power that afflicts people's health. This perspective allows us to see illness and healing in a context that transcends the mere individualistic approach so often adopted by modern medicine, and which incorporates social, cultural, psychological and spiritual elements as well as physical. ${ }^{15}$

This approach opens up to a more experiential related interpretation of bodily healing, where one can see Jesus as one of several healers. Instead of seeing his healings primarily as instances of divine authority and call to faith, one can see them as expressions of God's care and will for the restoration of life in the body. This approach allows us to interpret his healing ministry about that of other healers, past and present, and to not place his ministry in a supernatural or miraculous sphere all by himself. Given this line of interpretation, Jesus as a healer would be displaying similar characteristics as other healers: a person endowed with special gifts which he can see as part of his personal calling to help people realize their place and position about God, and as witnessing about God's grace, care and compassion. ${ }^{16}$

The gifts of healing that Jesus possessed will still be possible to theologically conceive as given by the Spirit within such a perspective, and as something used by God both for the sake of the Kingdom of God and the benefit of humanity. As specific gifts that can also be experienced in other humans, the ability to heal can be an indication of what is possible at the level of humanity for people whom God decides to endow with specific capacities for alleviating the struggles, the pain and the misery of others. Accordingly, these gifts are not to be considered as working against nature or outside what is possible on the level of creation, but they are relatively rare and exceptional for a specific group of people that may be seen as called to use them in a particular ministry for others. When used in this way, healing contributes to a fuller realization of creation.

It is, from a theological point of view, essential to see the "generic" features of Jesus' healing ministry as something more or something else than what we can identify in the practice of other healers. This point has to do with theological concerns related to Jesus' special calling, and with how his healings functioned within the context of his proclamation of the kingdom of God. Against this backdrop, we can now formulate three main components in a sketch for a contemporary theology of healing that addresses the Gospel for the body.

\footnotetext{
15 This is a point that is emphasized strongly also in the article by Peters, op. cit.

16 Admittedly, to interpret Jesus' work as healer alongside or parallel to that of other healers is not uncontroversial. However, given present ethnographic material, this approach seems more likely as a context of interpretation than is a mere Enlightenment dismissal of his work as a healer altogether.
} 


\section{Healing as a sign: presence and revelation of God}

Nothing that happens to a body is possible to grasp without some interpretation. The mere encounter between healer and healee will always be attributed some significance by the parties involved, or by others. ${ }^{17}$ Although healing can take place in different contexts and be interpreted within different frameworks, for Christian theology, it is crucial not only to recognize this as a feature that makes such events open and ambiguous in terms of their interpretative potential. The recognition of the need for interpretation means that every healing also will have the character of a sign: it will point to something, mean something for someone in some respect or other. ${ }^{18}$

If we see Jesus' healings as signs or symbols of the kingdom of God, this approach allows us to become aware of an interpretative horizon that appears as profoundly fruitful. Symbols are real, and simultaneously they relate us to what they symbolize in a way that also affirms how they are different from their referent and thus cannot be understood as a substitute for the reality to which they relate us. ${ }^{19}$ Experiences of bodily healing can thus be seen as finite manifestations of the infinite reality of God. As finite experiences, they are concrete manifestations that are possible to experience and relate to and appreciate as part of our present world. At the same time, however, they are also pointing to something that is beyond what we experience here and now, as they re-present a reality that we cannot fully grasp, understand or partake in. Without making any decisions as to when and how we may be able to explain such healings, we can nevertheless affirm that as long as these events point to something both within and beyond the concrete embodied reality for the healee (or the beholder), healings may have a revelatory character. In the concrete, actual manifestation of the healing, the reality of God can be seen as manifesting itself. It is important to note, however, that it cannot happen unless some healing takes place: the healing is not a mere sign of the kingdom, but part of and manifestation of the Kingdom, albeit a finite one. The latter point here is what seems missing in Luther's interpretation of the stories referred to above.

If the healings of Jesus (and others) are then understood as broken symbols in the Tillichian sense, we can-even though they are not always taking place and not everyone is granted the chance to experience them-see them as signs of the kingdom. Even people who are healed eventually die; not all are healed, and some are only partially healed. Thus, the healings are themselves "broken" as long as the world's present conditions are what they are. In other words: Experiences of healing should not be seen as an opportunity to escape the conditions of this world but as signs of a reality that is not yet realized. ${ }^{20}$ As concrete and broken symbols, such healings testify to and reveal the care, compassion, and love of God that is not

\footnotetext{
${ }^{17}$ Cf. for many good analyses of this point Meredith B. McGuire and Debra Kantor, Ritual Healing in Suburban America, New Brunswick: Rutgers University Press, 1988, passim.

18 This way of articulating the sign-character implies that there are different levels or dimensions in the process of signification. I need not go deeply into those here. For a full-blown theory of this process within theology, based on the theory of C.S. Peirce, see Andrew Robinson, God and the World of Signs: Trinity, Evolution, and the Metaphysical Semiotics of C.S. Peirce, Boston: Brill, 2010.

19 I draw on Paul Tillich's use of symbols here. For an extensive analysis of Tillich's own theory of symbols, which fully addresses the distinction between finitude and the infinite, see Lewis S. Ford, "The Three Strands of Tillich's Theory of Religious Symbols," The Journal of Religion 46, no. 1 (1966), 104-130.

${ }^{20}$ See Peters, 301.
} 
yet realized fully in the world. Furthermore, their finite and broken character warns us, in good Lutheran fashion, against any theologia gloriae.

\section{Healing as grace}

From a theological perspective, when people are healed, it is not due to their qualities, their faith or their own merits. Healing is rather an expression of the grace of God in a human body, as this grace is manifest in the ministry of Jesus. The embodied character of Jesus' healings opens up to considerations about the relationship between nature and grace: as nature expresses itself in and through the human body, one can see the acts of grace for the healing of the body as something that engages with, presupposes, but also transcends the capacities of the body. Healing is enabling nature to become fulfilled or to be realized in new ways that are beyond the measures and capacities that the body can provide by itself.

In Lutheran theology, grace has traditionally been emphasized with regard to how it manifests God's forgiveness and mercy, God's favor, and donum. Grace overcomes the sinful human nature in the promise of the forgiveness of sins. This is a vital and essential part of Lutheran theology, but admittedly one-sided. Accordingly, grace is not something that substantially changes nature or transforms it in a way possible to experience. Alternatively, to put it more critically: Grace is seen as opposed to the experience of the outward person, and not something one should expect to experience except for in the faith of the "inner person."

With good reasons, Lutheran theology often has seen nature and grace as opposites, and sometimes they are. When grace works "against" nature, it is against the sinful nature of humanity and against the forces that impede and destroy the chances for health, goodness, beauty, and love in the world. However, in classical theological sources, such as in Thomas Aquinas, nature and grace also are seen as working in interplay. This perspective may have profound significance for the interpretation of bodily healing. Here, grace may build on nature and contribute to and condition its perfection (gratia non tollit naturam, sed perficit-grace does not destroy nature, but perfects it). ${ }^{21}$ The flip-side of this point is that there would be no grace unless there was an embodied nature in which and by which it could be realized. A Lutheran theology that takes God's interaction seriously as it comes to the fore in the experiences of bodily healing can thus see grace as relating to, building on, but not fully restricted or determined by nature in its present form. Grace reveals new chances for nature and presents it with new and surprising opportunities. This perspective is rooted in an understanding of God as the creative source of both nature and grace. As such, God allows for both freedom and independence, and for interplay and interaction. In this way, the grace implied in healing cannot be understood as supra-natural, but rather as intra-natural.

When we interpret healing from this perspective, we have a solid argument against any devaluation of the human embodied reality. Without the gracious acts of God in and with and for the body, the human being will not reach its final and eternal goal (telos) in terms of displaying the love, care, goodness, and beauty of

21 Summa Theologiae 1, q. 1, a. 8, resp. 2. 
God. Jesus' graceful interruptions, on the other hand, always provide new opportunities for this will to become realized. Furthermore, and second, the transforming power of grace in nature, as this is expressed in bodily healing, should not be underestimated. Grace not only supplements nature but changes it. This change can be seen, e.g., in how the graceful reception and the presence of a mentally-challenged child in a small community open up to new experiences of what it means to be a human for those who hitherto emphasized achievement and cognitive capacities as the only valuable elements in human personhood. And we can see it in how receiving the gift of forgiveness can change a person's selfperception and the way she orients herself in her social world. Grace transforms nature and the body.

As suggested, grace expresses God's unconditional love and God's favor that is not conditioned by any achievements of human agency. Furthermore, and closely related, grace is therefore also surprising, an unexpected gift, donum, as is often affirmed in traditional Lutheran theology. Grace is beyond the laws of nature, but still works in, with, and under them-sometimes in ways, we are not (yet?) able to understand. Therefore, healing grace can also be seen as an expression of God's freedom, a freedom that God then in turn also bestows upon those who experience his gifts as liberation from the past, and as opening up to the future.

The embodied character of healing, exemplified, e.g., in the laying on of hands, also suggest that healing grace can be realized in, by, with, and under the conditions of human life: it requires the concrete incarnation of God's manifestation of grace in nature. It is not so only in the case of Jesus as a healer, but also in the sacramental elements, in and in other embodied human beings that can display the gifting character of God for other embodied beings. Healing grace is also experienced as embodied grace.

\section{Healing and faith}

The relation between healing and faith is complicated. Many healing events call for a faith interpretation, but this fact does not mean that faith is a condition for healing to happen. Healing is not based on faith in Jesus as the Son of God or in a specific belief about his atonement for our sins. There is nothing that seems to indicate unambiguously that this is the case, neither in the New Testament material nor in more recent reports of healing. ${ }^{22}$ That faith is not a necessary condition for healing to occur is most clearly witnessed in stories about healings where the healees are not present, and where there is no indication of them having knowledge about others intervening on their behalf (cf. the son of the official in John 4:46, and the servant of the Roman officer in Luke 7:1-10).

\footnotetext{
22 This being said, though, there is also strong evidence that suggests that faith may have an impact on healing processes. Some healings that take place may be "explained" by the so-called placebo effect, but this effect is not sufficient to explain all healings that take place in the context of healers-including Jesus. It is also worth noting that even when there is such an effect as the so-called placebo effect, scientists are not totally convinced about what is actually happening. A thorough and fairly open-minded study of healing compared to alternative medicine and with reference to the placebo effect in both is found in T. J. Kaptchuk, "The Placebo Effect in Alternative Medicine: Can the Performance of a Healing Ritual Have Clinical Significance?," Annals of Internal Medicine 136, no. 11 (2002).
} 
To see bodily healings within the perspective suggested above, namely as signs of the kingdom of God, as broken symbols, and not as final evidence for the reality of the God whom Jesus proclaimed. It enables us to see healings as having similar features as sacramental elements: they are concrete and visible instances of the reality of the kingdom, although they consist of natural elements. Faith embraces the elements or the instances of healing as more than the natural and sees these symbols as both manifesting the actual and creative presence of God in the world, as transformations of the concrete created world (from illness to health), as well as bearers of promises for the future.

To recognize the possible element of faith in relation to healing means that instances of healing testify to the unity of the embodied human being: faith embraces the embodied character of healing, and thereby faith itself is strengthened and transformed. Thus, not only the body but also the soul and spirit, partake in the transformative processes of healing. The Cartesian divide between mind and body is refuted in this approach to healing, as the body itself is integrated into the wholeness of life to which faith opens up. The joy of becoming whole is emerging out of the actual occurrence of healing and health itself. To say that healing only has to do with how the mind perceives things, or with the body and not the soul or mind, is deeply misleading. When Jesus heals, one of the things that become visible is how the humans who relate to him are whole persons who long for wholeness (healing) in all experiential dimensions of life, because they belong together and are so deeply affected by the illness from which they suffer.

As the Spirit is the one who creates life, and life is always embodied life, healing of the body is for the sake of the fullness of the human being's life. So-called "spiritual healing" is never mere spiritual and has to do with more than the faith and hope of the mind: it opens up the healee to become more fully the person s/he was created to be. Healing may be seen as something that works on the conditions of the present world: not everyone is healed, not all are fully healed, and we still have suffering and death as enduring conditions of life as we know it. Therefore, healing can be considered as the work of the Spirit, because it creates hope and faith in the reality of the kingdom. Healing can, accordingly, not be understood or interpreted in isolation from its eschatological character-just as the sacramental reality of the church cannot be. There is an element of surplus in spiritual healing compared to that of the ordinary restoration of health, because of its embodied symbolic character. To see healings as the work of God does more than repeat and mirror already existing conditions of life, it is the witness to something beyond; the kingdom of God. The main point here may be to suggest that the one who is ill is not only ill: he or she is recognized in the kingdom as a whole person, created in the image of God, and thereby as one who is more than a passive person in need: he or she is even in his / her condition of illness also a witness to the gifts of God, and a receiver of God's caring love and compassion. The experience of being created in God's image and as one who is cared for by God is something that medicine alone cannot provide. This point is, in itself, a reason for a more holistic approach to healing that includes and acknowledges the spiritual resources that make humans become what they are. 